\title{
PALÁRIK'S LIBERAL-REFORM CONCEPT OF ADDRESSING THE SLOVAK ISSUE
}

\author{
Marcela Gbúrová ${ }^{1}$
}

\begin{abstract}
The Catholic priest, journalist, political analyst and playwright Ján Palárik was also involved in the Slovak national-awareness process in the 19th century. In the context of the Slovak political thinking, he is known as the founding personality of the liberal project of addressing the Slovak issue. This paper deals with three levels of this project. The first level concerns his liberal concept of the Slovak national politics. This concept was developed on the background of the liberal theory of the relationship between freedom and law as developed by the French philosopher Ch. Montesquieu. The basis of the second level of this project was in the differentiation in the ranks of the Catholic clergy, which manifested itself in the spring of 1848 in the Habsburg monarchy. Palárik developed the requirement that the Catholic priests could actively participate in public and political life in the interest of the Church, the faith, the believers and to develop the idea of religious ecumenism. The third level concerned the democratization of the Slavic ideology in Slovakia and Historic Hungary. His reform efforts aimed at removing from this idea a negative label of "Russian Panslavism" while at the same time gaining the dimension of realistic inter-Slavic cooperation.
\end{abstract}

KEY WORDS: Ján Palárik, liberalism, freedom, democracy, constitutionality, politics, Catholic clergy, Slavdom

\section{INTRODUCTION}

Ján Palárik (1822 - 1870) is mainly known in the Slovak society for his activity as a playwright. His three comedies - Inkognito, Drotár, Zmierenie alebo Dobrodružstvo pri Obžinkoch - thanks to their folk-educational focus and politically up-to-date themes, were the dramaturgical discovery of the national and foreign - Serbian (Mráz, 1931, pp. 621 - 624) repertoire of amateur theatres. They did not even disappear from the Slovak professional stage in the second half of the $20^{\text {th }}$ century (Rampák, 1955; Čavojský, 1970). Only a small part of the Slovak public knows this author of intelligent language (fluent in seven languages), a Catholic priest, as well as the publisher of the journals Cyril a Metod, Sokol and the fictional almanac Svornost' (published

${ }^{1}$ Dr. h. c. prof. PhDr. Marcela Gbúrová, CSc., Faculty of Arts, Pavol Jozef Šafárik University in Košice, E-mail: marcela.gburova@upjs.sk. 
in cooperation with Jozef Viktorín). The professional community of political scientists and historians perceives him as an active political journalist, a representative of the liberal wing of the Slovak nation-forming elite, one of the creators of the second Slovak political newspapers Pešt'budínske vedomosti (1861), the co-organizer of the founding of the Matica Slovenská national foundation (1863), the religious and cultural institution of the St. Vojtech Society (1870), and a new liberal oriented political group - The New Slovak School (1868). His progressive political views and solutions have not been sufficiently evaluated and interpreted so far. One of the earliest attempts to characterize the political and social activities of Ján Palárik was done by the literary scientist Michal Gašparík (Gašparík, 1952). The philosopher Tibor Pichler (Pichler, 1998, pp. 77-95) and the Catholic theologian Jozef Vavrovič (Vavrovič, 1993, pp. 13-198) opened the space for research of Palárik's liberal-reformist discourse in several areas of the Slovak political, social and Christian life in the $19^{\text {th }}$ century.

After Palárik the political ideas and values of liberalism were made more precise only in the Hlasist movement, which developed its activities in Slovakia in the late $19^{\text {th }}$ and early $20^{\text {th }}$ centuries. Milan Hodža, one of the protagonists of Slovak politics in the Czechoslovak Republic after the year 1918, who promoted the liberal principles of civil liberty and the democratic reform of the geopolitics of Central European nations in his political activity, reminded that liberalism would be enforced in the "Slovak world of ideas" with major difficulties (Hodža, 1930, p. 222). He was right, because liberal democracy was only being enforced with major complications in the Slovak political and public life even in the following historical development of Slovakia. It should be remembered that liberalism has the potential to create new party-political units, participate in the political profiling of the times, interfere with the qualitative level of the formation of civil society, but especially to develop its most original values in public and private life, such as individualism, freedom, justice, marker, contractual relations, human rights and others. In order to do this, a discussion forum should also be opened in the Slovak professional, political and public space to answer various questions related to the possibilities and prerequisites for the functioning of a liberally oriented society. For this reason, it is necessary to develop not just a discourse about its ideological, political, party, cultural, economic, sociological, political, ethical and social dimensions, but also about the historical context of its existence in the Slovak political thinking.

This paper is focused on the above direction. It opens up the question of Palárik's liberal concept of Slovak and Historic Hungarian politics in the $19^{\text {th }}$ 
century, and deals with two other related topics, namely Palárik's reformed Church policy and his vision of democratic Pan-Slavism.

\section{PALÁRIK'S REFORM SOLUTIONS FOR SLOVAK AND HISTORIC HUNGARIAN POLITICS}

Palárik's liberal views began to be formed in the Trnava Seminary (Palárik, 1901, pp. 38-39, 45-46, 50-52), where he became acquainted with the Enlightenment anthropology, which was considerably optimistic about the autonomy of civil society and the intellectual and moral identity of man. It was in this concept of man where he found the central principle of liberalism - the principle of equality in freedom and dignity. At the same time, as a priest, he took up the idea of religious freedom (tolerance) and the issue of modernizing the relationship between the Church and the State (separation of the Church from the State). Under the influence of the difference of opinion in the ranks of the Catholic clergy, which emerged in the spring of 1848, he began to deal more closely with the Enlightenment ideas and liberal-reform ideas. These ideas were promoted by a relatively liberal-minded priesthood and were being spread throughout the Habsburg monarchy. He accepted their request with understanding that the Catholic priests be able to actively participate in public and political life in the interest of the Church, religion, and believers. It is not incidental that at that time he was studying in detail the Hobbes' theory of social compact, the economic work of A. Smith, especially his Examination of the Nature and Causes of the Wealth of Nations (Palárik, 1956, pp. 150-157) and the liberal concept of the relationship between liberty and the law elaborated by the French political philosopher Ch. Montesquieu. The most famous work of this philosopher (De lesprit des lois (1748) was most frequently mentioned in his political papers, quoting from him the passages that related to the legal issues of civic and political freedom of citizens.

Montesquieu encouraged him to think about the crucial issue of the civil and political rights and freedoms of the national communities, the national (Slovak) identity, and the goals of the national Slovak politics. The fundamental leitmotif of the French philosopher's thinking is freedom, democracy, and constitutionality. It is this leitmotif that entwines throughout Palárik's entire journalistic activity and interferes with his Church-reformist views. As a liberal-oriented Christian intellectual, he primarily departed from the concept of the rule of law, this means from a natural understanding of human rights and their claims on the function of the political arrangement. 
Palárik became one of the first Slovak patriots to realize that constitutionality is a sphere where a diverse symbolic activity is concentrated, a sphere where society has the opportunity and prerequisites to fulfil its citizenship with active content. For this reason, he was highly perceptive to the quality of the relationship between the level of the democratization of society and the understanding of its constitutionality. It was also thanks to Montesquieu that he understood that constitutionality did not merely cover the basic rules of interpersonal communication and the way in which State bodies are constituted, but also the goals and ideals and moral standards of a given society. He noticed a new, and it should be emphasized that a very important, element in the principle of constitutionality, whose author was Montesquieu. This philosopher incorporated into the theory of political power the power of the judiciary, which not only fundamentally changed Locke's triad of power, especially its third article. At the same time, he contributed to further negation of absolutism because he made problematic the hundreds of years old institution of the European monarchy that embodied the divine law. By doing that, he opened up the way to shaping the modern concept of constitutionality.

After the laws adopted by the Historic Hungarian Assembly in the years 1848 and 1849 and after the October Diploma (October 20, 1860) marking the end of the Estates society and the beginning of the creation of a new - civic type society in Hungary, a space was created for Ján Palárik for a political debate related to addressing the Slovak issue by the constitutional means within the framework of Historic Hungarian constitutionalism. He considered the Hungarian state "the primary framework of Slovak politics and the Hungarian parliament as a place of its creation" (Pichler, 1998, p. 83). His Austro-scepticism began to form after the events of the revolutionary years of 1848/49, and at the time of the Bach Absolutism, which he politically evaluated in the sense that Vienna was unable to secure the natural principle in the multi-ethnic area of the Habsburg monarchy. He expressed this view in several political contributions from the 1860s, clearly declaring it after the Austro-Hungarian Constitutional Settlement in 1867 in three politically fundamental treatises: Účel Austrie pod centralizmom a dualizmom (The purpose of Austria Under Centralization and Dualism) (Slovenské noviny, 1868, No. 33-34, 38-39, 41-42), "Nová Škola" (The New School (Slovenské noviny, 1868, No. 36), Odpoved' p. Júliusovi Plošicovi na „Stanovisko Starej slovenskej školy" (A Reply to Mr. Július Plošica on the "Standpoint of the Old Slovak School) (Slovenské noviny, 1868, No. 72 - 73, 78 - 79). 
He even considered the dualist arrangement of the Habsburg Empire an even worse variant of the state-law concept than a monarchist regime. He departed here from an Enlightenment argument on the "special" ("natural", "realistic", "useful") purpose of the State-political entity. According to him, the aim of the Habsburg monarchy was, as he stated in the Purpose of Austria under the Centralization and Dualism (Slovenské noviny, 1868, No. 33), the promotion of a "proud" German policy, i.e. Germanization ("culture-bearing role") towards the East and the special purpose of Hungary was "putting a barrier to a powerful stream of Germanization eastward (...)." He saw the cause in the Hungarian political elite, who, like the Viennese elite, "has also taken the same fixed and unhappy goal for themselves, namely the rule of the Hungarian element and the violent Magyarization" (ibid). He believed that the Austrian-Hungarian settlement not only did not take into account the ethnic (constitutional) principle of the federalist division of the monarchy, but that instead of dualism, two centrals with their two separate purposes were created: The German and the Hungarian ones. In this respect, he had a clearly profiled idea, which consisted of a bit of a non-traditional concept of "perfect dualism," meaning, in the personal union of two separate federal states - Austria and Hungary - linked by the common ruler and common interests (ibid.). He saw in it greater possibilities for addressing the natural national-emancipatory processes and issues related to the issues of forming a civil-type society.

Interestingly, in his reformist political solutions, he also admitted trialism, which, besides the Hungarian and the Austrian states (he perceived the latter as German-Slovenian), was to include the Czech state as well. The reason for such a step was seen in the weakening of the political power of the Austrian and Hungarian states in the possibility of the institutional arrangement of some territorial self-governing units (in The Reply to Mr. Július Plošica to the Opinion of the Old Slovak School (Slovenské Noviny, 1868, No. 78) especially the Slovenian, the Galician, and the Ruthenian ones).

We have noted that Palárik saw space for Slovak politics in the area of the Historic Hungarian statehood. His idea of reaching agreement with the Historic Hungarian governmental political representation in the pursuit of Slovak demands was clear and intelligible. He presented it openly in 1861 at the time of the Memorandum events (Holotík, 1963, pp. 3-29, Bokes, 19401941, pp. 278-280) when, in the strategic political question of the Martin Assembly, he took a critical stance on the proposal for the definition of a special Slovak territory (Slovak district) prepared by Š. M. Daxner. Together with J. Nemessanyi and other representatives of the more liberally-oriented 
Slovak national intelligentsia, he described this demand as an institutionally above-the-standard, anti-Viennese, provincial, politically unpredictable and as harmful from the viewpoint of seeking communication with the Hungarian political and governmental circles. In his political calculations, he was guided by a "step-by-step" tactic. Therefore, he did not consider the formation of the Upper Hungarian Slovak Neighbourhood to be the primary role of the Slovak political representation. He drew attention to political prudence in the sense that "the Slovak nation, insofar as it is possible, did not stand up to the resistance with the Hungarian party, represented by the Land Assembly, but sought to hold against the Centralist-German party by retaining its national rights, as for the time being they would not be granted. Later making them effective in practice through any means permitted by the Constitution." As a realistic political analyst, he emphasized that "now we are left with nothing more than just acting with the forces we have (...) and subsequently to acquire as much land as we can within the given circumstances so that we can at least take some of it that might serve us as a basis for further action and new forces of acquisition" (Palárik, Priatel školy a literatúry 1861, No. 35, p. 2).

He considered, together with representatives of the New Slovak School (Kostický, 1959), the Slovak language as a starting point of the Slovak political representation in all the lower- and upper-level schools in Slovakia, administration, self-government, and patriotic education of young people. The stated framework of political requirements is an example of the fact that Palárik considered a priority - as opposed to the Old Slovak School, which was politically oriented to Vienna (Martinkovič, 2005, pp. 804-818) - the building of political power from the bottom up in the constitutional conditions of Hungary. He did not see realistic possibilities (Podrimavský, 1981, pp. 406-519; Hajko, 1979, pp. 333-345, Potemra, 1978, p. 150 and subs.) for the maximalist goals of the Hurban-Daxner alternative to the solution of the Slovak issue. Moreover, he feared that this alternative could definitively block cooperation with the Slovak-speaking nobleman and the city intelligentsia. In its political attitudes, it was - especially for economic and pragmatic reasons - more loyal to the leaders of Hungarian politics than the national-emancipatory goal of the Slovak politically disunited representation that did not offer it an attractive political and economic vision. The stated threshold requirements for the participation of Slovak citizens in the management of public affairs in the area of the Hungarian state were, according to Palárik, not just a generous and passionate step towards a fair solution to the Slovak issue but also a test of the degree of 
democracy of a given political system. It turned out, quite early, after the Austro-Hungarian Settlement, and especially after the adoption of the 1868 law act on nationalities that the system was not willing to accept those democratic demands.

In his attempt to find opinion-forming political allies on the Hungarian side, Palárik publicly denoted Pest as the main management centre of Slovak politics and culture (Pichler, 1998, p. 91) and at the same time subscribed to the progressive liberal political opinion of the New Slovak School which published the following in the first issue of its press body, the Slovak Newspapers: 1 . Solidarity, equality, freedom; 2 . The principle of democracy; 3. The idea of national Hungarian federalism. On the pages of these newspapers, he further developed his "concept of Slovak Historic Hungariananchored liberalism, by which he wanted to address the Slovak issue in a constitutional way, within the Hungarian homeland" (Pichler, 1998, p.83). The Enlightenment framework of constitutionality has been a great help in highlighting the legal aspects of modern citizenship, including the value of independence - a patriotic attitude towards the country that has been defined by statehood principles and the national identity, that is, a feeling of belonging to a community of a new type - the nation. He recognized political support in the Hungarian liberal political representation, particularly József Eötvös and Zsigmund Kemény, whom he avowed. He regularly followed the liberal press: Pesti Napló, Pester Lloyd, and Magyar Sajtó. Palárik was very close - after 1848 - to the idea of municipal autonomy, where he assumed the rapid social, economic, and administrative-legal development of local self-government (cities and districts) and ethnic identity of Slovak citizens. In this regard, it has to be emphasized that he often referred to the Pester Lloyd's Hungarian liberal spirit, in which he found his political ideas. For example, the fact that citizens themselves decide on the electoral act, the language of which nationality will be the official language of their "district". He valued the policy of the Minister of Education and Culture, Baron J. Eötvös, very high, a liberal Catholic with humanistic and Christian ideas whose political aim was a centralized parliamentary State, liberal State education, and the application of the principles of liberty, equality, and tolerance in the ecclesiastical-political sphere (Hrabovcová , 2000, p. 156). He cited many of his opinions. He particularly appreciated the one, which was a fundamental political response to the 1848 National Assembly Law Act: "Only strictly abiding by the laws of the year 1848 our country can save itself from the dangers of national grievances; on the contrary, we have to worry about national trenches if we are to resign from the sphere of equality, on which the 
supreme laws of both of the nationalities stand" (Palárik, 1956, p. 46). As an example of the implementation of this view, Palárik presents a meeting in Liptov, which the majority of the population adopted the Slovak language as its negotiating language (Palárik, 1956, pp. 46-47). He also appreciated the attitudes of liberal publicists from the liberal Pesti Napló magazine.

T. Pichler highlights two examples that could have positively inspired J. Palárik to take liberal values as his political creed. In the first case, it is Lukács's anti-Palárik reformist stance consisting in the following: the issue of nationalities should become a Europe-wide issue and the issue of the official language in Hungary could be resolved in such a way that in order not to disrupt the functioning of the State, the official language would be Hungarian and at various levels of State government and local authorities (municipality, district, assembly) the use of the national languages should be approved; the language of the proceedings in the Assembly would be Hungarian, with representatives of nationalities having the right to use their mother tongue. The second example is the opinion of M. Desančić, editor of the Austrian Ost und West newspaper, which suggests that Palárik's attitude, who preferred the Hungarian political framework to the Austrian one and "built" on the Historic Hungarian Constitution of 1848, was not merely his personal attitude, but one of the viewpoints in contemporary Slavicoriented journalism (Pichler, 1998, pp. 84-85).

At the same time, he was drawing attention to the Hungarian political culture, which, according to him, was based on constitutionality, while cautiously informing the political circles of Pest that they would not get the sympathy of Europe by not addressing the national issue (Pichler, 1998, pp. 85-87). In spite of Palárik's policy of moderation, concessions and consensus with relevant Hungarian political elites, it turned out after 1868 that the Hungarian political leaders considered not understanding but assimilation as the ideal means of addressing the issue of nationalities. They differ only in the choice of means. Palárik's sympathizer J. Eötvös apparently reconsidered his moderate liberal position of the 1850s, as evidenced by his politically speculatively formulated attitude of 1867 . He nationalistically argued that liberal methods of concessions and moderation would only need to be used for assimilation purposes. They are, according to him, "more effective than violent methods, and that if Hungarian culture coped with the role of assimilation, it would demonstrate its natural superiority and moral strength" (Viator, 1955, p. 158).

At home, Ján Palárik wanted to achieve two national-political goals: The first one was the national education "from below" implemented through 
the Slovak language, the second one was in gaining the Slovak middle class. While he was too lonely to accomplish the second goal, he lacked a politically and ideologically more sophisticated programme to offer to this layer of the Slovak population, not to mention the absence of necessary contacts to relevant political circles of Pest, he needed even more energy to achieve the first goal. He was aware that engaging Slovak citizens, especially the common people, in the critical interpretation of laws (not only those of 1848) and in the political process would not be a simple political role. He was very well aware of the problems of creating their legal, political, and civic awareness. He knew that if they did not at least acquire the basics of active citizenship within a relatively short period of time, they would not be able to judge the public norm of justice, the public morality of the law, or the basic policy of the Hungarian State. It was important for him - as he emphasized - to "make positive" (Palárik, 1956, pp. 63-67) the use of the civil and political rights that they had acquired after March 1848 laws. Therefore, he drew attention to the necessity of national upbringing and political education. In this respect, he liked to quote from the work of Montesquieu, who defined the absolutist style of governance ("Rigorous obedience presupposes ignorance and blindness on the part of the one who obeys") and a way of dealing with the idea of sovereignty of the people (Palárik, 1956, p. 64).

Palárik presupposed the necessity of at least a threshold level of political culture for the representative type of democracy, education about politics, and the use of the "language" of those who have a decisive "influence on law-making, municipal and country management (...), otherwise that nation may (...) use power and influence in a bad way, for their own and general destruction ... "(Palárik, 1956, pp. 65-66). He did not treat these elements of representative democracy as merely a theoretical issue, but he politically tried to apply them in the initial contradiction between the constitutionally designed civic and political freedom of the inhabitants of the "Hungarian Lands" and the language dictates (Hungarian became exclusively the official language of the whole of Historic Hungary) which was the result of the Hungarian Assembly of Deputies in 1847/48 in Pressburg. It was on this type of contradiction on which he outlined the issue of the relationship between the national and the civic principles. It should be noted that Palárik had all the prerequisites to develop this important political topic from a political and practical point of view. Unfortunately, he left only a sketch, but it also shows his democratic thinking and a relatively progressive concept of civic and national identity. 
Palárik did not attribute a special status to the national principle, but he perceived it as part of the civic and political freedom of an ethno-social community: "The civil and political freedom of the people includes the freedom of nationalities, which is founded on freedom of conscience and conviction, and consequently it is identical with religious freedom, the oppression of which is the sin against the freedom of conscience and religion, which cannot be tolerated in a free State in any way" (Palárik, 1956, pp. 66-67). He understood the civic principle as a wide array of distinct identities, including the national identity, which he perceived primarily as an issue of language. $\mathrm{He}$ derived the distinctiveness of national identity from the "inalienable" and "irremovable" nature-divine essence, to which no human law can be superior. In this context, he pointed out very strongly the "terrible" legislative and political inconsistency committed by the Hungarian legislative assembly in 1848: "The introduction of a foreign language as a language of a general council, an official and academic language, is not just a manifest limitation of the political and civic rights of the people and thus the abolition of the nature of the constitution, which is also an obstacle to the general edification, education and political maturity of the people, which is the basis of the State and the main condition of its co-existence and development" (Palárik, 1956, p. 66). In interpreting this legislative incoherence, J. Palárik departed from the liberal political concept of public justification, which presupposed rational reasoning communication, critical thinking, public dialogue, and respect for the diversity of opinions.

In the context of this concept, his opinion should also be considered on the issue of the nature of the relationship between the law and the nature (basis) of governance. Interestingly, he also referred in this case to Montesquieu's position, according to which "in every State the laws must be in the most consistent manner with nature, that is, the nature and the basis of governance" (Palárik, 1956, p. 68). The choice of this quote is a proof that Palárik stood in the issue of the emancipatory idea of constitutionality on the position of the Enlightenment theory of social compact and natural law, which obliged the State to respect and protect the natural rights and liberties. The Assembly law acts of 1848, in particular the $16^{\text {th }}$ Article mentioned above, violated this compact by removing the natural right of non-Hungarian nationalities to use their language in municipal and regional assemblies and councils. The politically damaging consequences of this legislative incoherence were that the Slovaks, the Serbs, the Romanians and other nationalities in Historic Hungary, were given the lawful right to vote in their general and regional assemblies and committees but could not use the native languages 
of these nations. In this way, political and civic freedom has been restricted in particular to those citizens who have failed to speak the official language or did not sufficiently master it. A wave of resistance raised against the $16^{\text {th }}$ Article of the Constitutional Law Act, following the adoption of the constitutional law in the non-Hungarian national communities of Hungary. Palárik said in the article Inconsistency of the Assembly of Deputies of the Year 1848 that "at the national meetings in the Region of Nitra and at the Regional Assembly in Liptov, the people unanimously concluded that in the public assemblies, committees and courts the language of the local people, i.e. Slovak, be used as the language of debate and management. The same was demanded and concluded by the Serbs, Croats, Saxons, and Romanians"(Peštibudínske vedomosti, 1861, No. 7, p. 2). The dissatisfaction with the absolutist element in the law had to finally be resolved by the Historic Hungarian Assembly, which was held in Seged in July 1849. It made a correction in admitting equality to the Hungarians before the law by the non-Hungarian peoples in Hungary and at the same time giving them the right to use their mother tongue in schools. It should be noted that the Hungarian politicians did not take a sincere effort to correct the legal incoherence, but rather to gain nonHungarian nationality on their side at a time when the Kossuth army had problems, resulting in their failure in the Battle of the Romanian village of Világos.

Given that, like John Locke, Palárik considered natural rights from the perspective of their divine origin, as can be seen from the above-mentioned characteristic of national freedom, his critique of the problem has not only political, but also moral and theological-philosophical dimensions.

Ján Palárik experienced great disappointment after the adoption of the Law Act on Nationalities on December 1, 1868. What he had reproached in the Law Act of 1848 was not even removed by this law act. On the one hand, it refused to recognize the nationalities as the State's own subjects (according to the Constitution, all the citizens of the Historic Hungary created, with the exception of the Croats, an indivisible Hungarian nation whose members they were regardless of their nationality) further it questioned the complete equality of the Hungarian peoples that it was conditional on the needs of the State, and finally confirmed Hungarian as the official language used in the State, the language of the Parliament, the Government, the governing bodies, the language used by the county representations and their officials, courts and universities. As far as the use of different languages of the State was concerned, they could, according to this law act, be used, but only to help preserve the unity of the country and if it was within the scope of 
practical possibilities of government and administration. The law should have been liberally conceived, but its final form (the preamble and the law act itself), which was being formed under the pressure of political radicals in the Parliament, testifies to the contrary. Palárik probably did not consider it meaningful and politically clever to comment on the problematic principles set out in the preamble and in the individual provisions of this important law act, therefore he chose another tactic: on the pages of the Slovak newspapers, he tried to draw attention to the Hungarian ruling circles on these issues by moral appeals. In particular, his three contributions of 1869 testify to this: National Selfishness (Slovenské Noviny, 1869, No. 53), National Selfishness - Damage to the Nation (Slovenské Noviny, 1869, No. 54), National Hatred (Slovenské Noviny, 1869, No. 58-69). Their basic leitmotif is the issue of national selfishness.

Palárik did not talk about nationalism, yet he was apt to diagnose it precisely. He synonymized it with the term of "national selfishness", clearly identifying which ethnicity was affected by this moral disease of national supremacy. He accurately distinguished between righteous and unfair love. A fair love for him was the one that originated in "the natural life instinct of self-preservation, and in full accordance with the holy purpose of the Creator, seeking to make individual people, families, nations, humanity, reach according to his holy will on earth, and, of the greatest material and spiritual perfection of blessing " (Palárik, 1998, p. 153). So, on the one hand there was family love, national feeling, love ("beautiful", "noble" and "holy") to the nation as to a "natural family of families" linked by a common language and a "higher" love for humanity, on the other (principled) whose bearers love their nation more than the belief in God. In this connection, Palárik considered it necessary - in the name of justice - to remind all those who were affected by this moral disease, but also those who had the preconceptions to become infected by it: "... national selfishness will not become the germ of the great acts ... but a fruitful mother (...) of national luxury, unjust bouts, disgraceful national hatred, friction and disarray, all sorts of criminals, violence and injustice, in which no State, this embodiment of the moral idea, can and will not stay for long. (Ibid). The events on the Hungarian political scene after 1868 fully confirmed Palárik's assumption of the character of the aggressive nationalism. 


\section{PALÁRIK'S ECUMENICAL CONCEPT OF THE REFORM OF THE JOSEPHIAN-ABSOLUTIST STATE-CHURCH SYSTEM}

The power-political changes in the year 1848 also gave the Churches the possibility of reforming the Josephian-absolutist State-Church system. The constitutional reconstruction of the State caused many Catholic priests to invoke a greater degree of autonomy and freedom, arguing, as evidenced by the Memorandum of the Catholic Bishops in Bratislava on March 20, 1848, that the Protestants "have for long enjoyed their Churches under the supervision of the State which they themselves manage" (Hrabovcová, 2000, p. 158). The Hungarian Episcopate Memorandum impartially responded to a Hungarian religious law which, in the spirit of the liberal principles, enshrined the full equality and reciprocity for all the confessions, without mentioning anything about the relationship between the Church and the State, which actually preserved the previous state of affairs. Neither the Memorandum of April 8, 1848, requesting the creation of Catholic autonomy with the participation of the general lay public in Hungary, did not receive a direct response from the interested parties. The indirect response was taken by the opponents of Catholic autonomy during the Revolution of 1848, especially L. Kossuth, who was the advocate of general secularization and State funding to the Church, and the advocate of the Calvinist model of the Presbyterian-Synodal Church Organization. An additional indirect answer to this Memorandum was the Education Act, which was based on the liberal principle of civic equality and state-guaranteed equal access to education, with the aim of eliminating the system of confessional education and replacing it with a secularised education based on the State-civil principle and the principles of morality without religion (Hrabovcová, 2000, pp. 159-165). The failure to adopt this law act (not passing through the Upper Chamber of the Parliament) meant the liberal-secularization, anti-cleric (sometimes openly anti-Catholic) slowing down policies of the Hungarian Revolutionary Government, but at the same time it was a signal for the Catholic clergy to mobilize the clergy and laity to actively participate in the administration of the Church. The problem of achieving this participation had shown the difference of opinion in the ranks of the Catholic clergy itself. On the other hand, this disparity in opinion was positive in that it caused the need to carry out reforms of the intra-Church life, which at that time was demanded by a major part of the priests and the lay public.

Ján Palárik was closely observing those tensions of the Church-political character in the revolutionary period of 1848/49 in Historic Hungary. As a 
Catholic priest of the liberal reformist foundation, he was seeking the ways out of the situation in which Christianity occurred after the power-political changes in the Habsburg Monarchy. Inspirationally, he was impressed by the book by Jozef Miloslav Hurban, Union, That Is a Union between Lutherans and Calvinists in Historic Hungary (Hurban, 1846), in which he found not just a realistic view of the political dimension of the union of the Evangelicals and Calvinists in a unified Church organization but also the author's view of the implementation of an ecumenical idea: "The only possible Union, the only one for that, which we may call the holiest duty of Christians, is that which brings together all the Churches on the basis of Christ's teachings, on the dogmas of everlasting, unchangeable, indescribable, but admitting differences that are not based on these dogmas (...) The Union between us and Calvinists will not be possible unless they break away from their teachings, or we will cease to believe" (Hurban, 1846, p. 180). Palárik even recommended Hurban's book as an instructional reading for Slovak Catholics and Evangelicals, in which they may find "a sincere love of truth, enthusiasm for the Christian religion, and a certain sympathy for true Catholicism in general" (Cyril a Metod, 1850, No. 6, p. 123).

Hurban's ecumenical stance became Palárik's starting point for his ecumenical stance, which he presented in the years 1850 and 1851 on the pages of the first Slovak Catholic journal Cyril a Method, whose editor he was from its first issue (March 14, 1850). He presented his basic theses on 19 March 1850 in the discipline of the parish church in Vindšachta (later Piarg, today's Štiavnické Bane) and in several reflections published by Cyril a Metod: The Speech on St. Joseph's Day, the Pentecost of Jesus Christ, on the Fall of Religion, Told in the Temple of Vindšachta and Published at the Request of Those Well-Believed (Cyril a Metod, 1850, No. 2, pp. 9-12, No. 3, pp. 25-26, pp. 34-35); Thoughts of and Reflections on all the Christian Denominations (Cyril a Metod, 1859, No. 10, pp. 81-83, 1850, No.15, pp. 121-124, No. 21, pp. 169-170, pp. 177-179, No. 24, pp. 193-196); Cyril and Methodius Review (Cyril a Metod 61-63, No. 9, 1850, No. 6, pp. 52-54). These may briefly be characterized as follows: 1 . Eradicating the unbelief as a kind of spiritual uprising that has broken the unity of the Christian Church, made Christians, made Christians enemies of their own, destroyed trust among the people, and corrupted the moral principles of Christian life; 2 . Reviving the perishing faith on the basis of the ecclesiastical reforms carried out at the ecumenical councils, diocesan and provincial synods; 3 . Introducing Christian-national education of young people; 4. Uniting the Slovak Catholics, Evangelicals, Orthodox believers, and Calvinists on the principle of piety, true Catholicism 
("Christian-Catholic faith as the only right and saving") in order to strengthen the cultural, religious, and political development of the Slovaks.

The problem of Palárik's ecumenical attitude was in the interpretation of two concepts that had the basic meaning: 1. "Self-salvability" of the Catholic Church, 2. Catholicism, or the universality of the Church. As confirmed by his controversy with Evangelical Mikuláš Dohnány (Cyril a Metod, 1850, No. 24, pp. 195-196), no major changes of opinion could be expected on this issue, on either side. In order to succeed in his unifying efforts, especially with the Slovak Evangelicals, Palárik should not have, in our opinion, opened up the topic at all because it concerned the conceptual differences in the teachings of both Churches. In this respect, neither the other amicable solution he addressed in the assessment of the three possible paths of ecumenism ("absorbing", "moderated", "conservative") by the German author Lindenbauer was acceptable to the Evangelicals. Ján Palárik was of the opinion that unification can be done in an absorbing-moderated form, so that the absorbing-moderated method (one of the Churches would renounces its doctrine) would apply to matters of faith, and the moderate process would include rituals and external signs (mode details in Cyril a Metod, 1850, No. 24, p. 179). Palárik's proposal was not practicable, and it even demanded certain reforms in the life of the Catholic Church, which demanded a welcoming approach from the part of the conservatively thinking episcopate favouring the idea of a unified and largely independent feudal Historic Hungary under the rule of the Habsburgs (a typical representative of this part of the episcopate was also the Primate of the "glorious Kingdom of Hungary" and Archbishop of the Estergom Archdiocese, Ján Scitovský, with whom Palárik got in a dispute for his editorial activity that has greatly damaged his renown not only in his own ranks, but mainly with the patriots affiliated with the Old Slovak School) and for his Church-reformist opinions published in Cyril a Metod. For example, he claimed the priests' affairs be transferred to the diocesan courts and treated impartially, he proposed that the former practice of the councils and diocesan synods be put into effect, reforming the issue of the material state of the Church and its moral life, the changes of the Church institutions, the separation of the Church from the State, the special Church administration, material provision of priests and the construction of seminaries for the clerics, establishment of the Slovak archbishopric in connection with the County Primate and other issues of the Church life (see Cyril a Metod, 1851, No. 1, pp.1 - 5 for more details).

Palárik was not successful in his ecumenism, whose basic principles were transferred to his Pan-Slavic concept (religious unity in the womb of Slavic 
nations leading to the unification of all the Christians). However, it has to be said that he could not have been more successful in the specific historical conditions in which he lived. After Jozef Miloslav Hurban, it was him who developed the idea of co-operation among Christians in the 1850s, which, as it turned out, found its merit in a broader Christian, especially Catholic, community. It is also to be remembered that the ideas of ecumenism were also adopted by Pope John XXIII, who wrote in his first Encyclic, Ad Petri Cathedram (1959) specifying the purpose of the Second Vatican Council: "The main purpose of this Council is to raise the Catholic Church, to save the moral renewal of the Christian people and the adaptation of the Church discipline to the needs of our time. It will surely be a beautiful expression of unity, truth, and love. We hope that, when viewed by those who are separate from this Apostolic See, they will feel the sweet desire for unity in which Jesus Christ so earnestly prayed to the Heavenly Father"(Vavrovič, 1993, p. 99).

\section{PALÁRIK'S IDEA OF SLAVIC SOLIDARITY AND THE HUNGARIAN POLITICAL CONTEXT}

As the protagonist of the New Slovak School, Ján Palárik was a supporter of preserving the integrity of the Historic Hungarian State, but on a federal principle. After analysing the political situation in this multi-ethnic State body, he believed that only a federal form of coexistence would bring the development of every non-Hungarian nation in Hungary. For this reason, he began to deal with the Pan-Slavic idea and the idea of its application in the political conditions of Historic Hungary in the first half of the 1860s. This idea, which was created in the Budapest milieu (then the centre of the Slavic intellectuals), was presented by him in a paper on Slavic Reciprocity, from which the Sokol magazine (1862, No. 1) published its introductory part, with the entire text having been published in the Lipa magazine in the year 1864 (Palárik, 1956, pp. 173 - 192).

In conceiving his idea of Slavic reciprocity, Palárik wanted to follow up on the positive ideas of the main reporters of Slavic ideas in Slovakia - Ján Kollár, Pavol Jozef Šafárik, and Ludovít Štúr - and reforming it simultaneously so that it lost the negative label of the "Pan-Slavic Russian Monarchy", acquiring at the same time a dimension of inter-Slavic cooperation. For this reason, he critically evaluated Kollár's and Štúr's conception of Slavic reciprocity. He reproached Ján Kollár for his cultural pan-Slavism. He emphasised that limiting Slavic reciprocity to "buying books and reading Slavic books" is a form of useless mystification that damages the political interests of Slavic 
nations and does not correspond to the realistic needs of the cooperation of Slavic national societies in and outside of Historic Hungary. In connection with the concept of political Pan-Slavism of L'udovít Štúr, which emerged at the end of his political career and life path, he reminded that the emergence of a studious "Pan-Slav" State established under the auspices of the Russian Tsar would be a very bad variant in terms of a modern democratic form of power. His attitude was rationed by the following four reasons:

1. It would discredit Slavism as a form of power balance; 2. It would destroy the notion of Slavic solidarity in the eyes of Poles; 3. It would strengthen Russia's conviction of its political dominance over the remaining Slavic world; 4. It would exasperate the public opinion of the citizens of Western Europe against the Slavs who have associated pan-Slavism with pan-Russianism.

Palárik based his pan-Slavism on Christian values, on liberal civic principles, on the equality of Slavic nations and on their free co-operation (within the framework of Historic Hungarian constitutionalism and beyond): "Slavic solidarity leaves alien nations and governments in peace, it does not violate any rights of others, it does not ask for what belongs to another entity, but it just wants that the law of the Slavic nations be respected by the others, namely by the ruling governments, and that the national development and prosperity of the Slavs be developed in the countries in which they reside (...) Therefore, the Slavic solidarity then does not lead to uniting all the Slavic tribes under a single government, not to the founding of a single giant empire (...), but it only aims at taking a direction that each individual tribe acquires under its special government more national autonomy, self-government and freedom, or a separate, independent and free community with others, as well as independent and free municipalities of the Slovak in no other but voluntary union of mutual love, the need for at most national associating beneficial for our nation (...) The true direction of pan-Slavism is purely liberal, because any supremacy of physical or moral entity over another one is the effect of violence resulting in injustice, oppression, enslavery that cannot exist in the realm of true freedom!" (Palárik, 1956, p. 183-185, 192).

Thus, Palárik - unlike the "post-revolutionary" L. Štúr, J. M. Hurban, S. H. Vajanský and other Slovak Russophiles - did not represent the unification of the Slavs within a single State with an absolutist governmental system. On the contrary, he wanted coexistence in equality before the law of Slavic and non-Slavic nations within multinational State formations. At the same time, he predicted the formation of multinational federations on democratic principles. It was very important for him to resolve the Russian-Polish 
relations, which he considered to have been the central issue of the concept of Pan-Slavism. He attempted to resolve this issue in his historical tragedy Dimitrij Samozvanec. Palárik created in it a fictitious figure of the sovereign a fake Dimitri of the $19^{\text {th }}$ century, a reformed, socially solidary, fair democratic Pan-Slav, seeking an alliance between the Poles and the Russians in a federal union that would form the basis of a federation of free Slavic nations (both Ukrainians and Byelarussians). Palárik's idea of resolving this dispute was based on the transformation of the Tsarist absolutism into a democratic State through social reforms and the abolition of villeinage. Rapprochement of the Catholic and Orthodox Churches could inspire the builders of the great idea of ecumenism. Although this tragedy did not win the jury's sympathy in the dramatic theatre plays called by the Matica Slovenská national foundation for understandable reasons (Palárik's hero did not meet the criteria of the contemporaneous aesthetic norm and his solution to the Polish-Russian issue was diametrically different from the majority opinion of the Old Slovak School), (Ďurišin, 1957, pp. 273 - 296, Čavojský, 1955, pp. 233-244), he did present a solution that had a modernizing political framework.

\section{CONCLUSION}

Palárik's Christian-liberal concept of addressing the Slovak issue was progressive from the viewpoint of political science, correlating with the modernization trends of the whole Historic Hungarian society, but in the political contexts of Historic Hungary, and within them the Slovak political contexts, it was only feasible in its particulars. His liberal concept of politics, political work, civil rights, the relationship between liberty and constitutionality, as well as his active and authentic participation in the administration of Church affairs and the creation of modern Slovak and Slavic national identity are evidence that the solution of this issue had another alternative in the 1850s and 1860s than the one historically perturbed - the maximalist programme of cultural and political institutionalization of the Slovak nation, promoted by the Old Slovak School. The emerging Slovak political elite, mostly from the ranks of the conservative deputies like Jozef Miloslav Hurban, was at that time less flexible as to attitudes and politically. For this reason, they were not prepared, perhaps even not willing, to conduct a constructive dialogue with representatives of Slovak liberalism, which they considered to be a "fifth column" of anti-Slovak oriented Hungarian liberal politics. Palárik remained largely alone in his political orientation but with a personal political conviction that "the national goals are most 
effectively achieved by the application and use of civil rights and freedoms" (Pichler, 1998, p. 78). Any subsequent forms of addressing the Slovak issue are evidence that his conviction was not just an empty rhetorical figure.

\section{REFERENCES}

BOKES, F. (1940-1941). Mad’arské prejavy protimemorandové, volume 1861. In: Historica Slovaca I-II. 1940-1941, pp. 278 - 280.

CYRIL a METHOD. (1850). Vol. 1, No. 1, 6, 22.

ČAVOJSKÝ, L. (1955). O pôvodnosti Palárikovho dramatického diela. In: Slovenské divadlo. 1955, Vol. 3, No. 3, pp. 233 - 244.

ČAVOJSKÝ, L. (1970). Život za život. Príležitostná metodická príručka k oslavám 100. výročia smrti Jána Palárika. Bratislava: Osvetový ústav 1970.

ĎURIŠIN, D. (1957). Palárikova tragédia Dimitrij Samozvanec. In: Slovenské divadlo. 1957, Vol. 5, No. 4, pp. 273 - 296.

GAŠPARÍK, M. (1952). Ján Palárik a jeho boj o demokratizáciu slovenského národného života. Bratislava: SAV 1952.

HAJKO, D. (1979). Filozoficko-svetonázorové aspekty diela Š. M. Daxnera. In:

Filozofia, 1979, Vol. 34, No. 2, pp. 333 - 345.

HODŽA, M. (1930). Články, reči, štúdie. I. Praha 1930.

HOLOTÍK, L'. (1963). Memorandum slovenského národa z roku 1861. In: Historický časopis, 1963, Vol. 11, No. 1, pp. 3 - 29.

HRABOVCOVÁ, E. (2000). Revolúcia 1848 a katolícka cirkev v Uhorsku. In: Slováci v revolúcii 1848-1849. Volume of papers. Martin: Matica slovenská, 2000.

HURBAN, J. M. (1846). Unia čili spojení Lutheránů s kalvíny v Uhrách. Budín, 1846.

KOSTICKÝ, B. (1959). Nová škola slovenská. Príspevok k problematike národnostnej otázky v Uhorsku v 2. polovici 19. storočia. Bratislava: SAV, 1959.

MARTINKOVIČ, M. 02005). Idea slovanskej vzájomnosti v interpretácii predstavitelov Novej školy. In: Filozofia. 2005, Vol. 60, No.10, pp. 804 818.

MRÁZ, A. (1931). Palárikova divadelná hra Inkognito na srbských javištiach. In: Slovenské pohlady. 1931, Vol. 47, No. 10, pp. 621 - 624.

PALÁRIK, J. (1850). Posúzení Cyrillo-Methoda. In: Cyril a Method. 1850, Vol. 1, No. 6, pp. 52 - 54; No. 7, pp. 61 - 63.

PALÁRIK, J. (1850). Reč na sv. Jozefa, pestúna Ježiša Krista o upadnutí 
náboženstva, $\mathrm{v}$ chráme Vindašachtském pověděna a na žádost dobře smýšlejících uvěrejněna. In: Cyril a Method. 1850, Vol. 1, No. 2, pp. 9 12; No. 3, pp. 25 - 26; No. 4, pp. 34 - 35.

PALÁRIK, J. (1859). Myšlénky a spojení se všech krest’anských vyznání. In: Cyril a Method. 1859, Vol. 1, No. 10, pp. 81 - 83; No. 15, pp. 121 - 124; No. 21, pp. 169 - 170; No. 22, pp. 177 - 179; No. 24, pp. 193 - 196.

PALÁRIK, J. (1861). Na dorozumenie. In: Priatel' školy a literatúry. 1861, Vol. 3, No. 35, p. 2.

PALÁRIK, J. (1861). Nedôslednost' snemových zákonov, volume 1848. In: Pešt'budínske vedomosti, 1861, volume 1., No. 7, p. 2.

PALÁRIK, J. (1868). „Nová škola“. In: Slovenské noviny. 1868, Vol. 1, No. 36, p. 2.

PALÁRIK, J. (1868). Odpoved’ p. Júliusovi Plošicovi na „Stanovisko Starej slovenskej školy“. In: Slovenské noviny. 1868, Vol. 1, No. 72 - 73, 78 - 79.

PALÁRIK, J. (1868). Účel Austrie pod centralizmom a dualizmom. In: Slovenské noviny. 1868, Vol. 1, No. 33 - 34, 38 - 39, 41 - 42.

PALÁRIK, J. (1869). Národná nenávist'. In: Slovenské noviny. 1869, Vol. 2, No. $58-69$.

PALÁRIK, J. (1869). Národné sebectvo - skaza národa. In: Slovenské noviny. 1869, Vol. 2, No. 54, pp. 2 - 3.

PALÁRIK, J. (1869). Národné sebectvo. In: Slovenské noviny. 1869, Vol. 2, No. 53, pp. 2 - 3.

PALÁRIK, J. (1901). Autobiografia. In: Literárne listy. 1901, Vol. 11, pp. 38 $39,45-46,50-52$.

PALÁRIK, J. (1956). Za reč a práva l'udu. Kultúrnopolitické články. II. Zväzok .Bratislava: SVKL, 1956.

PICHLER, T. (1998). Národovci a občania: O slovenskom politickom myslení v 19. storočí. Bratislava: VEDA 1998.

PODRIMAVSKÝ, M. (1981). Slovenské dejiny v diele Š. M. Daxnera. In: Historický časopis. 1981, Vol. 29, č, 4, pp. $506-519$.

POTEMRA, M. (1978). Právnohistorická argumentácia v slovenskom národnom programe v polovici 19. storočia. In: Právěhistorické studie. Praha 1978.

RAMPÁK, Z. (1955). Veselohry Jána Palárika. In: Veselohry a divadelné prejavy. Bratislava: SVKL 1955.

VAVROVIČ, J. (1993). Ján Palárik (Jeho ekumenizmus a panslavizmus). Martin: Matica slovenská 1993.

VIATOR, S. (1995). Národnostná otázka v Uhorsku. Bratislava: Slovakia Plus 1995. 